\title{
Andrej Rabsztyn, L'écriture et le langage dans le roman épistolaire français et polonais de 1760 à 1820
}

\section{Regina Bochenek-Franczakowa}

\section{(2) OpenEdition}

1 Journals

\section{Édition électronique}

URL : https://journals.openedition.org/studifrancesi/26287

DOI : $10.4000 /$ studifrancesi.26287

ISSN : 2427-5856

Éditeur

Rosenberg \& Sellier

\section{Édition imprimée}

Date de publication : 1 avril 2007

Pagination : 177

ISSN : 0039-2944

\section{Référence électronique}

Regina Bochenek-Franczakowa, « Andrej Rabsztyn, L'écriture et le langage dans le roman épistolaire français et polonais de 1760 à 1820 », Studi Francesi [En ligne], 151 (LI | I) | 2007, mis en ligne le 30 novembre 2015, consulté le 23 novembre 2021. URL : http://journals.openedition.org/studifrancesi/ 26287 ; DOI : https://doi.org/10.4000/studifrancesi.26287

Ce document a été généré automatiquement le 23 novembre 2021.

\section{(c) $(1) \odot$}

Studi Francesi è distribuita con Licenza Creative Commons Attribuzione - Non commerciale - Non opere derivate 4.0 Internazionale. 


\title{
Andrej Rabsztyn, L'écriture et le langage dans le roman épistolaire français et polonais de 1760 à 1820
}

\author{
Regina Bochenek-Franczakowa
}

\section{RÉFÉRENCE}

ANDREJ RABSZTYN, L'écriture et le langage dans le roman épistolaire français et polonais de 1760 à 1820, Uniwersytet Slaski, Katowice 2005, pp. 244.

1 L'auteur examine le problème du rapport spécifique entre l'écriture et le langage réalisé dans la lettre fictive, dans une perspective à la fois théorique, historicolittéraire et comparatiste, celle-ci mettant en rapport le roman par lettres en France et en Pologne dans la période du tournant des Lumières. La notion-clé de l'analyse est celle du «mimétisme formel» adoptée d'après Michail Growinski; elle permet de considérer les lettres (fictives) des romans choisis par le biais des traits constitutifs de l'écriture épistolaire en tant que telle. La spécificité du statut du roman par lettres, forme hybride alliant le romanesque et l'épistolaire, a imposé ici une double perspective, déterminée par les deux niveaux de communication distincts. L'Auteur a divisé son analyse en deux volets, examinant d'abord les éléments péritextuels (titres et préfaces) qui créent un «contrat de lecture» spécifique. La comparaison entre les romans français et polonais de l'époque examinée s'est révélée instructive: l'Auteur a constaté que les mêmes conventions de la fiction épistolaire sont susceptibles de servir des objectifs différents, le roman par lettres polonais étant privé de la distanciation propre au roman épistolaire français. Le second volet de l'analyse est centré sue l'écriture épistolaire considérée au niveau de la communication entre les personnagesépistoliers: l'Auteur se penche sur l'emploi et la fonction de ces éléments de la lettre authentique qui marquent les lettres fictives du cachet du «mimétisme formel». Le métadiscours épistolaire, illustré ici par de nombreux exemples, s'avère riche en significations qui dépassent les seules conditions de l'écriture: la lettre, dans sa 
fonction pragmatique de substitut de la présence du (de la) partenaire absent(e), est sujette à accueillir des projections fantasmées de l'amour et des sentiments.

2 L'étude est fondée sur les théories modernes de l'épistolarité, mais encore, nourrie de la réflexion historico-littéraire et comparative. Le chercheur polonais ne perd jamais de vue l'objectif qu'il s'est posé: dans le cadre de chacune des parties de son ouvrage, il esquisse l'évolution de l'emploi des éléments épistolaires examinés dans les romans de la période qui s'étend sur soixante ans. Enfin, la prise en considération des romans par lettres polonais constitue le mérite incontestable de cet ouvrage qui permet d'élargir la connaissance du roman de l'Europe du tournant des Lumières. 